\title{
Implementation of Tourism Management Concept in Herbal Tourism Village as Alternative Tourism Business in the New Normal Era
}

\author{
I Gusti Bagus Rai Utama \\ Dhyana Pura University, Bali, Indonesia \\ Corresponding Email: raiutama@undhirabali.ac.id \\ Ni Made Diana Erfiani \\ Dhyana Pura University, Bali, Indonesia \\ Dermawan Wuruwu \\ Dhyana Pura University, Bali, Indonesia \\ Putu Chris Susanto \\ Dhyana Pura University, Bali, Indonesia \\ I Putu Darmawijaya \\ Dhyana Pura University, Bali, Indonesia \\ Christimulia Purnama Trimurti \\ Dhyana Pura University, Bali, Indonesia
}

\begin{abstract}
The novelty of this paper is in applying the downstream innovation in the tourism concept into herbal tourism village as alternative tourism in the new normal era. This project assistance is an implementation of the results of previous research related to tourism villages, especially the Catur Tourism Village, Kintamani, Bali as a form of implementation of herbal tourism villages as alternative tourism in the new normal era towards innovation in the downstream tourism concept of the herbal tourism village. The results of this project assistance can strengthen homestay-based tourism villages in Catur Tourism Village by strengthening homestay management so that the attraction of overnight tourism increases following the standards of hospitality, cleanliness, health, safety, and environment and health procedures in the era of adaptation to new and post-pandemic habits. Lifting, creating, and selling the potential for natural, agro, herbal, and cultural tourism, through assistance in exploring, packaging, and presenting tourist attractions as something to see. Empowering and instilling the values of excellent service quality local tour guides in eco-tourism exploration as something to do. Empowering tourism village managers and villagers in developing tourism products based on the principles of Sapta Pesona, including developing and packaging Catur Village souvenir products as something to buy, so that tourists get a thorough tourism experience.
\end{abstract}

Keywords. tourism villages, cleanliness, health, safety, environment 


\section{Introduction}

During the Covid-19 pandemic that is currently hitting Indonesia and even throughout the world, tourism village as one of the elements of tourism is certainly very affected. The decline in the level of tourist visits, adherence to health protocols for both service providers and tourism service providers, and the uncertainty of the future are challenges for all tourism personnel, including tourist villages. The Ministry of Tourism and Creative Economy of Indonesia has compiled a Protocol on Cleanliness, Health, Safety, and Environmental Sustainability in the field of Tourism (CHSE) in the tourism and creative economy sectors (Ministry of Tourism and Creative Economy, 2020). The protocol CHSE is intended for all parties, from managers, owners, associations, employees or tour guides, guests or visitors, community groups, and local governments. The research conducted will be an academic evaluation related to the protocol CHSE, in the fields of hotels, restaurants, attractions, homestays, spas, travel businesses, special interest tourism activities, and so on. The adoption of the protocol CHSE in the model for shaping the competence of human resources in the tourism sector, the quality of public health protection in the tourism sector can increase, and the trust of tourists in tourism destinations in Indonesia is increasingly trusted.

In addition, the Ministry of Tourism and Creative Economy of Indonesia continues to prioritize the concept of sapta pesona and excellent service in the tourism sector, including its implementation in tourist villages. Sapta Pesona is aimed at providing satisfying and organized services in carrying out tourism activities, as well as providing an overview of services that will be applied in a tourist spot which makes the formation of a prime habit to be applied in conducting tourism business (Setiawati \& Aji, 2020). Sapta Pesona consists of seven elements, namely safe, orderly, clean, cool, beautiful, friendly, and memorable. The awareness of the tourism village community about Sapta Pesona, as the host in the tourist village, must also be accompanied by the ability of the tourism actors in the village to implement excellent service. Excellent service is the provision of the best service to meet customer expectations and needs, meet quality standards to achieve satisfaction (Setiawati \& Aji, 2020).

In addition, CHSE Ministry of Tourism Creative Economy of Indonesia, sapta pesona, and excellent service, the development of a tourism village that is in line with the direction of the must also follow the principles and stages of exploring, packaging, and presentation in developing potential tourism products. The stage exploration aims to understand, change and shape the personal character and superior products in the tourism village. After exploring the potential, the stage packaging aims to educate and improve the competence of the tourism village manager. After that, the stage presentation aims to determine market segmentation according to the capacity of the tourism village. It can be emphasized that the concepts and stages of exploring, packaging, and presentation do not only emphasize the aspects of physical tourism products, but especially the development of reliable, creative, competitive human resources who are ready to explore tourism potential in their area, and with the right assistance. creating attractive, uniqueness and high selling power packages, as well as being able to convey their excellence and uniqueness in an attractive travel presentation.

This project assistance is an implementation of the results of previous research related to tourism villages, especially the Catur Kintamani Tourism Village as a form of implementation of the herbal tourism village as alternative tourism in the new normal era towards the downstream innovation in the concept of herbal tourism village tourism, Catur Kintamani, Bali, Indonesia has been supported by the Evangelical Mission in Solidarity (EMS), Germany. 


\section{Literature Reviews}

\subsection{Back to nature by tourism village}

According to Bali Provincial Regulation number 2 of 2012 concerning cultural tourism, a tourism village is defined as a tourism activity aimed at tourists to be able to enjoy the rural natural atmosphere that is used for resting, as well as studying the life of the local community and paying attention to the uniqueness of an area (Utama \& Junaedi, 2020). Tourism Village is a form of integration between attractions, accommodation, and supporting facilities that are presented in a structure of community life that is integrated with the prevailing procedures and traditions.

A tourism village is a form of tourism with tourist groups living and interacting in or near traditional life or in remote villages and studying village life and the local environment (Arida \& Pujani, 2017). This can be interpreted as an area with a certain area and has the potential for a unique tourist attraction that is unique to its community (Arida \& Pujani, 2017) which can create a combination of various tourist attractions and supporting facilities to attract tourist visits. The development of a tourist village can be an effort to foster local entrepreneurial potential, diversify tourism products, support the economy of the local community, and revitalize local culture.

Tourism villages are a form of rural tourism, which is a trip that is oriented to enjoying the atmosphere of rural life, respecting and obtaining added value to life from the culture and traditions of the local community (Arida \& Pujani, 2017). What becomes the object and attraction, in this case, is the daily life of the local community and its environment. The main attraction of rural tourism is the overall atmosphere that reflects the authenticity of the countryside, social life, economy, local community customs, building architecture, and distinctive village layouts (Depbudpar, 2001). The scope of rural tourism can be in the form of nature such as mountains, rice fields, forests, cliffs, landscapes, flora, and fauna, as well as marine parks; cultures such as historical relics, customs, traditions, daily life, and architectural works.

Furthermore, research by (Arida \& Pujani, 2017) requires eight (8) criteria for tourist villages are expected in a tourist village that is:

1) Nature or bio conservation, among others, includes landscape natural/ geographically unique and beautiful, and the phenomenon of biological uniqueness.

2) The physical environment, among others, includes the relatively unspoiled physical environment and traditional settlement patterns.

3) Culture, among others, includes village myths/legends, unique and distinctive traditional rituals, and sacred dance arts that are still alive.

4) Amenities, among others, include residents' houses that can be used as homestays.

5) Institutions include, among other things, a tourism village management agency that is working effectively.

6) Human resources, among others, include members of the community of productive age who are quite large and live in the village (> 30\%).

7) Attitudes and community lifestyles, including residents having positive perceptions of village tourism, and having an open mindset and friendly to outsiders, especially tourists.

8) Accessibility, among others, includes connecting roads to outside areas that are in good condition.

The main requirement for a tourism village is an appointment from the Regent. In its development, there are 4 (four) types or stages of tourism villages, namely pilot tourism villages, developing tourism 
villages, advanced tourism villages, and independent tourism villages. This classification is based on the number of visits, the tourism industry that is developing in the village, diversification of tourist attractions and activities, as well as growing amenities.

\subsection{Local ownership by community empowerment}

According to the Sustainable Tourism Charter, sustainable tourism development must be supported ecologically in the long term as well as being economically viable, ethically, and socially just to society (Charter for Sustainable Tourism, 1995). Recognition of local wisdom and support for the identity, culture, and interests of local communities must be the main basis for the formation of a sustainable tourism strategy. One form is empowerment through community-based tourism, rural tourism, and village tourism. Tourism that empowers the community is tourism which in its function and role is to support job creation, raise the economic level of the community, side with the poor, and side with environmental conservation.

In essence, empowerment is the creation of an atmosphere that allows the potential of the community to develop. This logic is based on the assumption that no society is completely powerless. Every society must have power, but sometimes they do not have it, or the power is still not known explicitly. Therefore, power must be explored and then developed. So empowerment is an effort to build power, by encouraging, motivating, and raising awareness of its potential and trying to develop it. In addition, empowerment should not trap the community in a dependency trap (charity), empowerment should instead lead to a process of independence.

A model of community empowerment with a 7D approach according to Dhamotharan (Kartika et al., 2019), begins by giving appreciation to the potential and achievements of the community as well as the pure values that exist in the community, followed by encouraging them to be aware of the availability of the resources they have. and analyze their strengths and weaknesses. The 7D approach consists of the following systematic steps:

1. D1-Developing relationship

2. D2-Discovering capacities

3. D3-Dreaming of community future

4. D4-Directions of community actions

5. D5-Designing community actions

6. D6-Delivering planned activities

7. D7-Documenting outputs, outcomes, and learning

\subsection{Development of tourism villages based on community-based tourism}

Tourism exists and grows due to differences, uniqueness, localities in the form of landscapes, flora, fauna, and the form of culture as a result of creativity, initiative, taste, and the human mind. Without that distinction, there would be no tourism, no people traveling or traveling. Preserving nature and culture and upholding diversity are the main functions of tourism. Nature and culture with all their uniqueness and differences are tourism assets that must be preserved. The loss of the uniqueness of nature and culture means that tourism is also lost (Ardika, based on the principle of uniqueness and locality, Indonesian tourism is based on the philosophy of life of the Indonesian nation itself, namely the concept of a sustainable life. Balanced human relations with God, balanced human relations with each other, balanced relations humans with the natural environment. This concept teaches us to uphold the noble values of religion and to be able to actualize them, respect human values, tolerance, equality, togetherness, brotherhood, preserving the natural environment. 
Currently, Community Based Tourism (CBT) has become a potential contributor to developing tourism. A clear example is when tourism is managed by involving the activities of the village community, the income from tourism activities has a direct impact on the economy of the village community, among others, their homeroom as a homestay (Utama \& Junaedi, 2020). CBT as a form of tourism that integrates environmental, social, and cultural aspects that are managed by local communities, provides opportunities for tourists to learn about the local community's lifestyle, spend time in areas rich in culture and biodiversity, as well as immerse themselves in the daily lives of residents (Susanto, 2016). Ideally, the CBT development process can empower the local community by building the skills, knowledge, and confidence needed for tourism development in the community directly.

There are many elements involved in developing CBT, which is often referred to as Penta Helix. This is an interaction and synergy between the five elements in tourism development, namely the government, the community (especially the driving force of tourism villages), industry/business, academia, and the media. The following is the role of each Penta helix element in community-based tourism development (Rizkiyah et al., 2019):

a) Government: the role of policy regulation, guidance, implementation, and supervision.

b) Local community: as business actors engaged directly / indirectly in the tourism industry, monitoring the impact of tourism on the culture and social community.

c) Business/industry: sources of business capital, creating jobs, recruiting local human resources as players in the tourism industry.

d) Academics: implementing training and developing tourism human resources, implementing scientific studies, implementing socialization, and mentoring community groups.

e) Media: promotional instruments, information distribution, and tourism image enhancement.

\section{Methods}

\subsection{Mentoring Program}

Empowerment of tourism village communities based on the mentoring program by higher education institutions carried out in Catur Village, Kintamani District, Bangli Regency, Bali Province. The distance between Dhyana Pura University and Catur Village is around 55-60 km with a distance of 1 hour 30 minutes if it is taken using a car.

The college-based tourism village assistance model implemented by Dhyana Pura University does not regardless of the pattern of assistance and empowerment of tourism village communities mandated by the Ministry of Tourism and Creative Economy. This model begins with the identification of the potential of a tourism village, which is then analyzed from its various elements (4A: Attraction, Access, Amenity, Ancillary) to find problems which are then examined through various studies (Astuti \& Puspaningrum, 2019; Darmawijaya et al., 2019; Krisnayanthi et al., 2019; Kutschenreuter et al., 2020; Sukarsih \& Erfiani, 2019; Susanto et al., 2018; Suyasa et al., 2018; Suyasa \& Widyastuti, 2020; Waruwu et al., 2020; Wulandari et al., 2018; al., Zeckel et al., 2020). The results of the research are used as recommendations, which are then realized for community empowerment in the form of training and mentoring while still paying attention to and developing networks with elements to Penta Helix and other support community-based tourism development. 
As development and application of a university-based tourism village assistance model, the Dhyana Pura University tourism village assistance team compiled a community empowerment model design based on college mentoring in Catur Tourism Village. This design is made based on the mentoring goals that have been set together with the elements of village leaders and tourism village managers, which include: (a) homestay managers, (b) tourism village managers, (c) Pokdarwis, (d) PKK and KWT. The issues raised are also relevant to conditions in Catur Village, in line with the Ministry of Tourism's vision of tourism development in the Covid-19 namely CHSE, development of holistic tourism packages (exploring, packaging, presenting), excellent service, "sapta pesona", and indeed the development of tourism products in the form of physical products and services.

\subsection{Community Empowerment Programs}

Models, designs, and roadmaps for community empowerment programs through university assistance by Dhyana Pura University at Catur Tourism Village can be summarized in a matrix which can be seen in Table 1 .

Table 1. Matrix of Community Empowerment Concepts in Catur Tourism Village

\begin{tabular}{|c|c|c|c|c|}
\hline Component & CHSE & \begin{tabular}{|l|} 
Exploring, \\
Packaging, \\
Presentation
\end{tabular} & Excellent Service & Sapta Pesona \\
\hline Concept & $\begin{array}{l}\text { Somewhere } \\
\text { To Stay }\end{array}$ & $\begin{array}{l}\text { Something } \\
\text { To See }\end{array}$ & $\begin{array}{l}\text { Something } \\
\text { To Do }\end{array}$ & $\begin{array}{l}\text { Something } \\
\text { To Buy }\end{array}$ \\
\hline Problems & $\begin{array}{l}\text { CHSE management } \\
\text { in homestays is not } \\
\text { optimal and must } \\
\text { comply with the }\end{array}$ & $\begin{array}{l}\text { The concept of } \\
\text { Catur Village } \\
\text { tourism has not } \\
\text { been structured }\end{array}$ & $\begin{array}{l}\text { No local tourism } \\
\text { actors }\end{array}$ & $\begin{array}{l}\text { Not many people } \\
\text { are aware of } \\
\text { tourism and take the } \\
\text { opportunity to }\end{array}$ \\
\hline Solution/ Activities & $\begin{array}{l}\text { CHSE training, } \\
\text { health standards in } \\
\text { the pandemic era, } \\
\text { homestay } \\
\text { management }\end{array}$ & Travel itinerary & $\begin{array}{l}\text { All understand } \\
\text { about the concept }\end{array}$ & $\begin{array}{l}\text { Tourism awareness } \\
\text { concept training, } \\
\text { development of } \\
\text { local souvenir } \\
\text { products (coffee, }\end{array}$ \\
\hline Objective & $\begin{array}{l}\text { Homestay Manager, } \\
\text { Tourism Village } \\
\text { Manager, } \\
\text { Pokdarwis }\end{array}$ & $\begin{array}{l}\text { Assistance in } \\
\text { exploration, } \\
\text { packaging, and } \\
\text { presentation of } \\
\text { tourism packages } \\
\text { and promotion }\end{array}$ & $\begin{array}{l}\text { Excellent service } \\
\text { training }\end{array}$ & $\begin{array}{l}\text { Pokdarwis, PKK, } \\
\text { UP2K, KWT }\end{array}$ \\
\hline Target & \multicolumn{4}{|c|}{$\begin{array}{l}\text { Capacity building of human resources in Tourism Villages according to Sapta } \\
\text { Pesona, } 8 \text { ASEAN CBT Criteria, CHSE protocol, excellent service principles, and } \\
\text { concepts of exploring, packaging, presentation. }\end{array}$} \\
\hline $\begin{array}{l}\text { Impact for Tourism } \\
\text { Village }\end{array}$ & \multicolumn{4}{|c|}{$\begin{array}{l}\text { Grade of Chess Tourism Village so that it is growing, approaching the Advanced } \\
\text { Tourism Village. There is a multiplier effect through the implementation of TOT } \\
\text { for key persons for each component. }\end{array}$} \\
\hline
\end{tabular}




\begin{tabular}{|c|c|c|c|c|}
\hline Component & CHSE & $\begin{array}{l}\text { Exploring, } \\
\text { Packaging, } \\
\text { Presentation }\end{array}$ & Excellent Service & Sapta Pesona \\
\hline Impact for Village & $\begin{array}{l}\text { Increa } \\
\text { throus }\end{array}$ & $\begin{array}{l}\text { om various st } \\
\text { e of the Touri }\end{array}$ & $\begin{array}{l}\text { lers. The welfare of } \\
\text { lage has increased. }\end{array}$ & lunity \\
\hline
\end{tabular}

\section{Results and Discussion}

\subsection{Tourism Village Catur, Kintamani, Bali}

The Bali Central Bureau of Statistics (BPS, 2018) noted that Bali had 110 tourist villages based on the latest calculations during 2018. This number increased to $124 \%$ compared to data collection four years ago. In addition, BPS also reported that the number of villages with tourist objects increased by $32 \%$ in 2018, considering that there were 162 villages with tourist objects, previously in 2014 there were only 122 . These data were obtained from the implementation of village potential data collection which was usually carried out three times. for ten years. The last data collection was carried out in May 2018.

Catur Village located in Kintamani is the 28th Tourism Village based on the Bangli Regent Regulation number 4 concerning Tourism Villages in 2018 (Bangli Regency, 2018). The village, which is located at an altitude of 1,250 m above sea level, is located at the western end of Kintamani District, which is famous for Arabica coffee and the area geopark Lake Batur, directly adjacent to Badung and Buleleng regencies. Its strategic location and adequate provincial road access are one of the strengths of Catur Tourism Village as an alternative stopover destination for Denpasar-Singaraja or DenpasarBatur trips (Susanto et al., 2018). Catur Tourism Village is $60 \mathrm{~km}$ from Denpasar city (travel time 90 minutes), $24 \mathrm{~km}$ from the Geopark Lake Batur (45 minutes), and $35 \mathrm{~km}$ from Singaraja (70 minutes).

The main attraction (anchor) of Catur Tourism Village is coffee agro-tourism. The coffee produced by Catur Village has been under the protection of the Geographical Indication "Kintamani Bali Arabica Coffee" since 2008 (Ardana, 2019). The 8 (eight) farmer groups subak existing, 3 (three) have processed their coffee cultivation to the processing, drying, roasting, packaging, and marketing stages with the labels Jempolan Coffee, Kecak Dance, and Mount Catur (Suyasa et al., 2018). The cultivation and processing of coffee specialty can be developed as a tourist and single origin, as in the era of coffee third-wave coffee lovers are increasingly interested in the origin of coffee, how coffee is processed, and how its presentation (Susan et al., 2019).

Apart from coffee tourism and beautiful mountain nature, Catur Village is unique in terms of culture with the acculturation between Balinese Hindu and Buddhist-Chinese cultures. The acculturation community lives harmonies with the Hindu community as the majority, and even gets a special place of worship (kongco) in the middle of the temple area Penyagjagan and a special grave for Chinese citizens from Catur which has the potential to be developed into tourism heritage (Susanto et al., 2018).

Another object related to Chinese mythology and cultural influences is Pebini Temple, a worship site for Dewi Danu as the protector of Lake Batur. The myth that still applies today is the prohibition to wear red clothes and jewelry when praying to Pura Pebini, which originated from Dewi Danu's jealousy of Kang Cing We - a Chinese princess who became the honey of King Jayapangus who was Dewi Danu's husband (Krisnayanthi et al. al., 2019; Sukarsih \& Erfiani, 2019). 
The results of the PESTLE analysis from the political, economic, social, technological, legal, and ecological aspects (Susanto et al., 2018) state that there is strong support from the village government, the district government. Bangli, the private sector (tour operators), and academics (Dhyana Pura University) for the development of Catur Tourism Village in the future. This analysis also shows that the main weakness of Catur Tourism Village is the lack of adequate accommodation and sufficient numbers for tourists to stay.

For this reason, Dhyana Pura University has collaborated with the government and the community of Catur Village to accompany the village since 2016. Dhyana Pura University, both lecturers and students, have been actively implementing various programs in Catur Village since 2017 and will continue until 2020. Some of these programs include (1) Community empowerment, especially women, through the cultivation of herbal plants and processing herbal products that are ready to be used and marketed (Program "Healthy, Equal, Prosperous with Herbs"), (2) Assistance for pre-village tourism by the Student Community Partnership Program team, (3) Empowerment of the Pokdarwis team in the field of serving food and beverages, (4) Assistance of the Pokdarwis team in the field of tour guides, (5) Assistance of coffee production business units in terms of packaging and branding, and (6) Development of Tourism Villages herbal based. Apart from cooperating in terms of programs, Dhyana Pura University also owns two plots of land in Catur Village covering 50 acres and 60 acres. The land area of 60 acres has been used as a mother garden for herbal plants since 2017.

The results of this study are expected to strengthen-based the CBT homestay in Catur Tourism Village by strengthening the management homestay, so that the attraction of tourism overnight is increasing (providing somewhere to stay) following the standards of hospitality, Cleanliness, Health, Safety, and Environment. CHSE), and health procedures in the adaptation era of new and postpandemic habits. Lifting, concocting, and "selling" the potential for natural, agro (coffee), herbal and cultural, through assistance in exploring, packaging, and presenting tourism tourist attractions as something to see. Empowering and instilling the values of excellent service quality local tour guides in mountain tourism exploration as something to do. Empowering tourism village managers and villagers in developing tourism products based on the principles of Sapta Pesona, including developing and packaging Catur Village souvenir products as something to buy, so that tourists get a thorough tourism experience (Utama, et al., 2021).

\subsection{Profile of training participants}

The implementation of the Catur Tourism Village mentoring program has at least 4 (four) target groups who are training participants and Dhyana Pura University's assisted partners, namely:

a) Homestay managers, totaling 8 people spread over 3 (three) banjars, namely the owners of Sudarma Homestay, Doublet Homestay, Bali Coffee Homestay, Dwija Homestay, Mandra Homestay, Mella Suter Homestay, K'cak Homestay, and Pondok Kenjung Homestay.

b) Pokdarwis, which consists of elders (kelihan) or representatives of 8 (eight) subaks namely Subak Abian (SA) Tri Guna Karya, SA Merta Sari, SA Tiying Seni, SA Pebunut, SA Pujung, SA Try Karya Nadi, SA Lalang, and SA Wana Sari Kenjung.

c) The Tourism Village Manager, which has been formed under Bundes. In training and mentoring activities represented by the chairman, secretary, and 6 other members.

d) PKK, UP2K, and the Women Farmers Group, especially in terms of preparing the typical and products of superior Catur Tourism Village (mainly herbal products), which during the pandemic period is limited to no more than 10-15 people per activity. 
In addition to the four main target partners, the Village Head (Perbekel), Bendesa Adat, the Chairperson of the PKK Activator, as well as elements from the youth organization in Catur village were also involved. In every training activity, the team always adheres to the health program that applies nationally, the special protocol in Bali province, as well as the pandemic health protocol that applies at Dhyana Pura University, including special community service protocols.

\subsection{Training and Assistance}

Implementation of the training and assistance is divided into 4 (four) series, namely training in the trainer (TOT) for lecturers and students, training in villages for target partners, centralized training carried out with the support of the Ministry of Tourism and Creative Economy, and advanced training in villages. The training activities can be described as follows:

1) Opening of the program: participants consist of the four elements of target partners in the 2020 training and mentoring program but are limited to not exceeding 25 people. On this occasion, the team conducted program socialization related to the material on Understanding Tourism Villages.

2) Training (TOT) for students and lecturers: training in the trainer (TOT) for lecturers and students who are involved in various training and mentoring activities in Catur Village, is also opened for students and lecturers who are or will develop a village-based community service program. Thus, it is hoped that the multiplier effect from the assistance activities of the Tourism Village of Catur can be realized and the impact of Dhyana Pura University is truly felt in the community. This activity was carried out on August 8, 2020, online and was attended by as speaker's/resource persons in activity this, 2 (two) lecturers who have participated in the TOT and received certificates as trainers of tourism village assistance.

3) Training in making herbal oil products as one of the tourism icons in Catur Village: because Catur is in a mountainous area, one of the herbal oils that many people ask for is rheumatic oil, in addition to the healing oil that has been trained in the previous year. This activity has target partners, namely the core cadres of UP2K PKK as supporters of tourism villages in creating products as something to buy, followed by 15 cadres.

4) The training on making functional drinks from empon-emponants and natural resources that are widely available in Catur village includes the drink "Sakuntala", which is a traditional herbal drink made from turmeric and betel as a typical drink served to guests/tourists, in addition to Kintamani typical Arabica coffee. In addition, they were also trained how to make the "Sale Manis" drink (lemongrass, lemon, and cinnamon) which was developed by the Chairperson of the PKK Catur Village with the Dhyana Pura University Team. The target of this activity on July 17, 2020, is that there are 15 members of the Women Farmers Group (KWT) who are cultivating the plants used as the basic ingredients of the drink.

5) Sapta Pesona and basic English training for KWT members and UP2K PKK core cadres, especially related to the vocabulary of herbal plants that have been cultivated in their respective fields and herbal products that have been produced and trained.

6) Training and mentoring for potential exploration, packaging, and presentations with participants from tourism village management elements and Pokdarwis. Due to restrictions on the number of participants in the activity, this training was only attended by 15 participants. In this activity, it was also discussed in depth the direction of developing a tourism village, especially concerning the pillars of existing tourist attractions, how to package them in one unit and how to present/promote. 
7) Training in making herbal Simplicia using natural drying methods: this activity has target partners, namely UP2K PKK core cadres as supporters of tourism villages in creating products as something to buy. Because the partners have cultivated herbal plants, the crops that are not processed into oil or beverage products can be dried by the partners so that they are not wasted. The result of this drying produces Simplicia which also has economic value so that it can become a souvenir product for the tourist village.

8) Homestay management training and assistance during a pandemic and CHSE for homestay managers. In addition to training and mentoring, the Dhyana Pura University team also provided material assistance to homestay managers in the form of new signboards, first aid, and hygiene and sanitation facilities to support the protocol kitsch.

9) Training on making Moringa Syrup and anti-mosquito herbal oil using local plants, namely moringa, and lemongrass. In addition to the Gotu kola syrup that was trained last year and has often been served to guests visiting Catur, the UP2K cadres want to diversify the products they can produce from local natural ingredients, so that they can add to the wealth of Catur's signature food and culinary icons, both as treats to guests, as well as souvenirs.

10) Financial Management Training in Tourism Village: after training in developing products, managing homestays, and designing tour packages, the Dhyana Pura University team also provided Pokdarwis, tourism village managers, and women elements (KWT and PKK) with financial management and marketing training in the context of tourism village management. Thus, the developed tourism products and service packages can be better managed, professional, and transparent.

After the training activity which was centered in Ubud, Gianyar on September 4, 2020, the Dhyana Pura University team resumed training and mentoring of the Catur tourist village in the village. Activities were delayed due to Galungan and Kuningan holidays, but the team and partners again carried out training and mentoring activities, with a focus at the end of the activity, namely homestay services and tourism village management, with materials on various service SOPs and tourism business management, which included training procedures for cleaning guest rooms and living areas, training in handling guest complaints, and training in providing important information and places of public service to guests. The activity was held on $18-19$ September 2020 and was attended by 20 participants, with the main material being products, services, and homestay management. Training and mentoring activities are also filled with discussions between various elements of stakeholders, to further unify vision and cohesion.

\section{Conclusions and Recommendations}

\subsection{Conclusion}

The Bangli Regency Government's support for the development of Catur Village as a tourism village is stipulated through Regent Regulation Number 4 of 2018 which relies on plantation products, natural beauty, cultural uniqueness, and superior herbal products. In this Government Regulation, Catur Tourism Village is in the 28th position out of 29 Tourism Villages in Bangli Regency. This sequence shows that the Catur Tourism Village is still new in its development. Through training and mentoring carried out by the Dhyana Pura University Team, the Catur Tourism Village was selected to become the representative of the Bangli Regency to participate in various competitions at the level of Bali Province. The results of the effort of the villager, Pokdarwis, the Tourism Village Manager, as well as the 
involvement of women elements through the PKK and KWT, of course with training and mentoring from the Dhyana Pura University team in the last two years, yielded very proud results, including $2^{\text {nd }}$ position in the provincial tourism village competition, $3^{\text {rd }}$ Place in the TOGA Competition, and Third Place in the Godevi Tourism Village Competition.

Some of the results and impacts of Dhyana Pura University's assistance in Catur Tourism Village in terms of outputs and outcomes are reflected in the Community Empowerment Concept Matrix.

1) Implementing the components of CHSE (Somewhere to Stay): After training and mentoring in 2020, the knowledge, skills, and facilities of CHSE homestay managers in Catur Tourism Village have improved, as evidenced by the presence and training of homestay managers regarding the checklist for homestay products, services, and management, most of which they have obtained. fulfill, and have fulfilled the elements of service procedures and health protocols in each homestay. Likewise, in terms of marketing, currently, homestays in Catur already have a digital presence, through Google Maps and listings on other travel web pages.

2) Exploring, Packaging, Presentation (Something to See) Components: Although not all stakeholders in the management of Catur tourism village have been able to capture the vision of village leaders related to tourism development in their village, entering the third year of tourism village existence, more and more stakeholders are involved in exploring, designing, developing, and promoting Catur Tourism Village. Not only that, the Penta helix elements that support tourism development are also growing, with the increasing number of CSR parties, universities, NGOs, tour operators, the government, and other related parties who are interested in helping Catur Tourism Village to grow. Dhyana Pura University as a pioneer in the development of the tourist village of Catur can be proud that his assistance has been able to develop rapidly. Until now, there have been several tour packages offered with various activities typical of Catur Village.

3) Sapta Pesona components and products (something to buy): From the various training and mentoring provided, Catur residents, especially women, are eager to support the development of tourist villages by developing herbal products as the superiority of the Tourism Village as well as their uniqueness compared to the surrounding tourist villages, which both rely on the mountain and agro natural tourism, namely Arabica coffee. single-origin. In 2020, there are many variants and diversification of herbal products from cultivation and processed by residents as part of the women's empowerment program, gender equality and social inclusion (GESI), and of course as supporters of tourism villages.

4) Excellent service component (something to do): The Dhyana Pura University team tried to open the minds of Catur residents as partners regarding their potential, as well as the direction of developing this potential. But in the end, it is the citizens who take action to develop the various components and potential of the existing tourism. Because in essence, empowerment is the creation of an atmosphere that allows the potential of the community to develop in exploring potential, motivating, and raising awareness, as well as leading to a process of independence. In 2020, several components or pillars of Catur Tourism Village are increasingly improving, including the coffeeproducing subak by opening the Catur Paramitha coffee shop which carries the theme of singleorigin and back to nature, as well as cultural/religious elements, namely by opening up penglukatan (place of cleaning). purification) in the area of Pebini Temple which does have its myth (Krisnayanthi et al., 2019). 


\subsection{Recommendations}

Based on the results of assistance in the second year (2020), based on tourism potential, it can be said that Catur has fulfilled four aspects (4A) in the offering of tourism products. Based on Attraction, Catur offers and further develops/strengthens 4 (four) main attractions, namely nature (natural beauty), agro (single-origin Arabica Kintamani coffee), culture, and religion (temples and assimilation of BalineseChinese culture), and herbs. In terms of accessibility, road access to Catur is very adequate, but the majority are still using private transportation, even though since 2019 the bus has been operating from downtown Bangli with the last stop is in Catur. In terms of Amenities, facilities such as homestays, food and beverage providers, banks, health services, and others are sufficiently available at Catur. Meanwhile, regarding Ancillary, the institution in Catur has led to full support for the development of tourism villages, but there is still a need to improve cohesion between industry, tourism village managers, and local business actors in the village.

Regarding its existence as a tourism village, Catur can still be categorized as a developing tourism village. This is based on several indicators, including visits that have started to exist and are increasing, but still sporadic, not continuous, and have not been traced by the tourism village manager regularly. The second indicator is the development of tourism support businesses in Catur, for example by opening a sanctuary at Pebini Temple, a coffee shop, and herbal products as souvenirs (something to buy) for tourists. This supports diversification and tourism activities, even though the village leadership has not designed it optimally, partly because it is still difficult to reach several natural tourism objects, such as multilevel waterfalls.

In addition, there are community members who have the potential to support tourism in the village but still take a wait-and-see position. Through training and mentoring carried out by Dhyana Pura University in collaboration with the Ministry of Tourism and Creative Economy in the last 2 (two) years, the readiness of human resources as managers of tourism villages has also increased, but not yet at an advanced level. Amenities are also growing, but not growing rapidly. Until now, there are only 8 homestay service providers with a total of 24 rooms ready for occupancy.

Regarding the criteria for a tourism village as stated by Arida \& Pujani (2017), it can be said that Catur Tourism Village has met the eight criteria that are expected to exist in a tourism village, at least partially, namely: natural elements, physical environment, culture, amenities, institutions, Human resources, attitudes and order of community life, and accessibility. The main priority in the coming year is the physical environment, namely the arrangement and cleanliness of the village, to make tourists more comfortable visiting. One of the efforts made by the village head is arranging a parking center for visitors and arranging public spaces so that they can be planted with herbal plants whose seeds are provided by the Dhyana Pura University herbal garden in Catur.

In addition, homestays as providers of amenities must continue to be supported and accompanied so that they are better managed, in terms of products, services, and management. Another priority is institutional, namely how the village designs institutions and good cohesion between village officials (both official and customary), Bumdes managers, tourism village managers, and Pokdarwis so that there is a unity of vision and direction for tourism village development.

In terms of developing a tourism village as a form of community empowerment, reflecting on the 7D (see Table 1) approach with seven stages, it can be said that the Catur Tourism Village is currently between D5 and D6, namely between Designing community actions and Delivering Planned Activities. In the previous stage, namely determining the direction of community action, it was clear that the village community wanted their village to lead to the realization of a tourism village. 
However, there is an impression that in its development, community empowerment through the tourism village program in Catur jumps from D4 to D6, namely from determining the direction to action, so that the community action design stage (designing/planning) gets less attention. This was the concern of the new Village Head (elected at the end of 2019), so he invited the community to conceptualize and redesign the vision and strategy for developing a tourism village in the future - including involving academic partners such as Dhyana Pura University. Actions taken in 2020, ranging from assistance to tourist lodges, developing herbal products, and training in tourism village management, may not produce instant results, but these are part of planning and preparation in realizing a tourism village that is increasingly developing in the future.

In terms of developing tourist villages in the midst of and after the Covid-19 pandemic, it can be said that Catur is still in the preparation stage for adapting to new habits. CHSE has been trained, and the means to comply with health protocols have been provided, but further assistance is needed to be able to get to certification CHSE (Clean, Health, Safety \& Environment) or Cleanliness, Health, Safety and Environmental Sustainability (Ministry of Tourism and Creative Economy, 2020).

\section{Abbreviations}

4A: Attraction, Access, Amenity, Ancillary; CHSE: Clean, Health, Safety, and Environment; Sapta Pesona: Safe, Order, Clean. Cool, Friendly, Memories; PokDarWis: Kelompok Sadar Wisata (Tourism Awareness Group); PKK: Pembinaan Kesejahteraan Keluarga (community organizations that empower women to participate in Indonesia's development); D1: Developing relationship; D2: Discovering capacities; D3: Dreaming of community future; D4: Directions of community actions; D5: Designing community actions; D6: Delivering Planned Activities; D7: Documenting Outputs, Outcomes, and Learning; TOGA is an abbreviation of Taman Medicinal Keluarga which functions as a drug provider as well as an aesthetic garden that meets the criteria for the beauty of the yard; ASEAN: The Association of Southeast Asian Nations; PESTLE: Political, Economic, Social, Technological, Legal, and Ecological aspects, CBT: Community Based Tourism; KWT: Kelompok Wanita Tani (Farmer Women's Group); UP2K: Upaya Penanggulangan Kemiskinan (Poverty Reduction Efforts); TOT: Training of trainer.

\section{Acknowledgments}

The authors are grateful to the Evangelical Mission in Solidarity (EMS), Germany, and Dhyana Pura University for supporting our project.

\section{Authors' Contributions}

I Gusti Bagus Rai Utama responsible for a final report, Ni Made Diana Erfiani responsible for project activities, Dermawan Wuruwu responsible for coordinator cultural project activities, Putu Chris Susanto responsible for marketing project activities, Sidhi Bayu Turker responsible for tourism product design project activities, Ni Luh Putu Christine Nama Suyasa responsible for homestay management project activities, I Putu Darmawijaya responsible for herbal project activities, and Christimulia Purnama Trimurti responsible for economic project activities;

\section{Availability of Data and Materials}

The datasets used and/or analyzed during the current study are available from the corresponding author upon reasonable request, email: raiutama@undhirabali.ac.id

\section{References}

[1] Ardana, K. (2019). Kinerja Kelembagaan Perlindungan Indikasi Geografis Kopi Kintamani. Agricore: Jurnal Agribisnis dan Sosial Ekonomi Pertanian Unpad, 2(1), Article 1. http://jurnal.unpad.ac.id/agricore/article/view/15073 
[2] Arida, I. N. S., \& Pujani, L. K. (2017). Kajian Penyusunan Kriteria-Kriteria Desa Wisata Sebagai Instrumen Dasar Pengembangan Desawisata. Jurnal Analisis Pariwisata, 17(1), 19.

[3] Astuti, N. P. W., \& Puspaningrum, D. H. D. (2019). Community Partnership Program Higiene Sanitasi Lingkungan Dan Makanan Kelompok Sadar Wisata (Pokdarwis) Di Desa Catur Kabupaten Bangli. Seminar Nasional Aplikasi Iptek (SINAPTEK), 0(0), Article 0. https://doi.org/10.36002/sptk.v0i0.894

[4] BPS Provinsi Bali. (2018). Provinsi Bali dalam Angka. Badan Pusat Statistik Provinsi Bali. https://bali.bps.go.id/publication/2018/08/16/9c43969415935571f5436925/provinsi- balidalam-angka-2018.html

[5] Darmawijaya, I. P., Erfiani, N. M. D., \& Waruwu, D. (2019). Pendampingan Kelompok Tanaman Obat Keluarga Menuju Keluarga Sehat Di Desa Catur, Kintamani, Bangli. Seminar Nasional Aplikasi Iptek (SINAPTEK), 0(0), Article 0. https://doi.org/10.36002/sptk.v0i0.808

[6] Kabupaten Bangli. (2018). PERBUP Kab. Bangli No. 4 Tahun 2018 tentang Perubahan Ketiga Atas Peraturan Bupati Bangli Nomor 16 Tahun 2014 Tentang Desa Wisata Di Kabupaten Bangli [JDIH BPK RI]. https://peraturan.bpk.go.id/Home/Details/88483/perbup-kab-banglino-4-tahun-2018

[7] Kementerian Pariwisata dan Ekonomi Kreatif. (2020). Protokol Kebersihan, Kesehatan, Keselamatan dan Kelestarian Lingkungan di bidang Pariwisata. https://chse.kemenparekraf.go.id

[8] Krisnayanthi, N. L. P. Y., Erfiani, N. M. D., \& Susanto, P. C. (2019). The Myth of Prayer Etiquette at Pebini Temple in Catur Kintamani: Structure, Meaning, and Social Function. KnE Social Sciences, 3(10). https://doi.org/10.18502/kss.v3i10.3936

[9] Kutschenreuter, A., Erfiani, N. M. D., Susanto, P. C., \& Regina, M. (2020). Marketing Strategies for Kopi Jempolan Brand of Catur Tourism Village Kintamani. International Conference on Fundamental and Applied Research (I- CFAR), 0(0), Article 0. https://doi.org/10.36002/icfar.v0i0.982

[10] Rizkiyah, P., Liyushiana, L., \& Herman, H. (2019). Sinergitas Pentahelix Dalam Pemulihan Pariwisata Pasca Bencana Erupsi Gunung Api Sinabung Di Kabupaten Karo, Sumatera Utara. Jurnal IPTA (Industri Perjalanan Wisata), 7(2), 247-256. https://doi.org/10.24843/IPTA.2019.v07.i02.p15

[11] Setiawati, R., \& Aji, P. S. T. (2020). Implementasi Sapta Pesona Sebagai Upaya Dalam Memberikan Pelayanan Prima Pada Wisatawan Di Desa Wisata Pentingsari. Jurnal Administrasi Bisnis Terapan, 2(2), Article 2. https://doi.org/10.7454/jabt.v2i2.98

[12] Sukarsih, N. N. T., \& Erfiani, N. M. D. (2019). Cerita Rakyat Raja Sri Jayapangus Di Desa Catur Kintamani: Pendekatan Struktur Dan Fungsi. Seminar Ilmiah Nasional Teknologi, Sains, Dan Sosial Humaniora (SINTESA), 2(1), Article 1. https://doi.org/10.36002/snts.v0i0.855

[13] Susanto, P. C. (2016). Peran Sektor Keempat Dalam Pariwisata Berbasis Masyarakat (Community-Based Tourism). Jurnal Ekonomi Dan Pariwisata, 11(2), Article 2. https://jurnal.undhirabali.ac.id/index.php/pariwisata/article/view/129

[14] Susanto, P. C., Adiada, A. A. K., \& Suyasa, N. L. C. P. (2018). Identification of Tourism Potentials in Catur Village Kintamani. Seminar Ilmiah Nasional Teknologi, Sains, Dan Sosial Humaniora (SINTESA), 1(1), Article 1. https://doi.org/10.36002/snts.v0i0.524

[15] Susanto, P. C., Sukmana, I. W. K. T., Puspaningrum, D. H. D., \& Stoffl, M. (2019). Menu Planning and Product Development for Single Origin Coffee Shop In Catur Village 
Kintamani Bali. International Conference on Fundamental and Applied Research (I-CFAR), 0(0), Article 0. https://doi.org/10.36002/icfar.v0i0.931

[16] Susanto, P. C., \& Suyasa, N. L. C. (2016). Exposing International Students to Social Entrepreneurship Concepts Enriched with Cultural Experience (SSRN Scholarly Paper ID 3016966). Social Science Research Network. https://papers.ssrn.com/abstract $=3016966$

[17] Suyasa, N. L. C. P. S., Setiawan, I. M. R. T., \& Regina, M. (2018). Kopi Arabika Jempolan Catur Village, Kintamani: Product and Promotional Mix Analysis. Seminar Ilmiah Nasional Teknologi, Sains, Dan Sosial Humaniora (SINTESA), 1(1), Article 1. https://doi.org/10.36002/snts.v0i0.507

[18] Suyasa, N. L. C. P. S., \& Widyastuti, N. K. (2020). Motivasi Mahasiswa Asing Memilih Bali Sebagai Destinasi Wisata Edukasi. Jurnal Ekonomi Dan Pariwisata, 15(1), Article 1. https://www.jurnal.undhirabali.ac.id/index.php/pariwisata/article/view/1071

[19] Undang-Undang Republik Indonesia Nomor 10 Tahun 2009 tentang Kepariwisataan, (2009). https://www.kemenparekraf.go.id/post/undang-undang-republik-indonesia-nomor-10tahun-2009

[20] Utama, I. G. B. R. (2014). Pengantar Industri Pariwisata. Deepublish. https://penerbitbukudeepublish.com/shop/buku-pengantarindustri- pariwisata/

[21] Utama, I. G. B. R., \& Junaedi, I. W. R. (2020). Membangun pariwisata dari desa: Desa wisata warisan budaya dunia Jatiluwih, Tabanan, Bali. Deepublish. http://repository.undhirabali.ac.id/597/

[22] Utama, I Gusti Bagus Rai et al. (2021). Exploring Key Indicators of Community Involvement in Ecotourism Management. Journal of Environmental Management and Tourism, [S.1.], v. $12, \quad$ n. 3, p. 808-817, June 2021. ISSN 2068-7729. Available at: https://journals.aserspublishing.eu/jemt/article/view/6123. Date accessed: 23 July 2021. DOI: https://doi.org/10.14505//jemt.12.3(51).20.

[23] Waruwu, D., Erfiani, N. M. D., Darmawijaya, I. P., \& Kurniawati, N. S. (2020). Pengembangan Tanaman Herbal Sebagai Destinasi Wisata Di Desa Catur, Kintamani, Bali. Panrita Abdi - Jurnal Pengabdian Pada Masyarakat, 4(1), 1-10.

[24] Charter for Sustainable Tourism, (1995). http://www.gdrc.org/uem/eco-tour/charter.html

[25] Wulandari, M., Susanto, P. C., Andityawan, I. M., Sinlae, J. B., Wiryadikara, R. P., \& Adiada, A. A. K. (2018). Pendampingan Kelompok Sadar Wisata Desa Catur Kintamani Menuju Desa Wisata Yang Kekinian. Seminar Nasional Aplikasi Iptek (SINAPTEK), 0(0), Article 0. https://doi.org/10.36002/sptk.v0i0.459

[26] Zeckel, S., Susanto, P. C., \& Erfiani, N. M. D. (2020). Market Potential of Cascara Tea from Catur Village Kintamani Bali. International Conference on Fundamental and Applied Research (I-CFAR), 0(0), Article 0. https://doi.org/10.36002/icfar.v0i0.1061 